Marquette University

e-Publications@Marquette

College of Education Faculty Research and

Publications

Education, College of

$11-2010$

\title{
Influences on Women Counseling Psychology Associate Professors' Decisions Regarding Pursuit of Full Professorship
}

Nathan Pruitt

Marquette University

Adanna Jinaki Johnson

Loyola University Baltimore

Lynn A. Catlin

Sarah Knox

Marquette University, sarah.knox@marquette.edu

Follow this and additional works at: https://epublications.marquette.edu/edu_fac

Part of the Education Commons

\section{Recommended Citation}

Pruitt, Nathan; Johnson, Adanna Jinaki; Catlin, Lynn A.; and Knox, Sarah, "Influences on Women Counseling Psychology Associate Professors' Decisions Regarding Pursuit of Full Professorship" (2010). College of Education Faculty Research and Publications. 131.

https://epublications.marquette.edu/edu_fac/131 


\title{
Influences on Women Counseling Psychology Associate Professors' Decisions Regarding Pursuit of Full Professorship
}

\author{
Nathan T. Pruitt ${ }^{1}$ \\ Marquette University \\ Milwaukee, WI \\ Adanna J. Johnson ${ }^{2}$ \\ Loyola University \\ Baltimore, MA \\ Lynn Catlin ${ }^{3}$ \\ Private practice \\ Madison, WI \\ Sarah Knox ${ }^{1}$ \\ Counselor Education and Counseling Psychology, Department of \\ Psychology, Marquette University \\ Milwaukee, WI
}

\begin{abstract}
Twelve women tenured as associate professors in American Psychological Association-accredited counseling psychology doctoral programs were interviewed regarding their pursuit of promotion to full professor. Interview data were analyzed using a modified version of consensual qualitative research. Most participants indicated a strong desire to be promoted and stated that they would not change their minds about

The Counseling Psychologists, Vol. 38, No. 8 (November 2010): pg. 1139-1173. DOI. This article is @ SAGE Publications and permission has been granted for this version to appear in e-Publications@Marquette. Sage Publications does not grant permission for this article to be further copied/distributed or hosted elsewhere without the express permission from SAGE Publications.
\end{abstract}


NOT THE PUBLISHED VERSION; this is the author's final, peer-reviewed manuscript. The published version may be accessed by following the link in the citation at the bottom of the page.

achieving this goal. Participants reported that their universities' guidelines for promotion emphasized a strong publication record and evidence of a national reputation, but participants often described these criteria as vague. Pursuit of full professorship was encouraged by having a current mentor, receiving supportive feedback about applying for promotion, and publishing noteworthy research. Pursuit of full professorship was discouraged by negative prior promotion experiences, feelings that colleagues did not value the participant's research, and conflicts between career and family obligations. Results are discussed within the context of Super's theory of career development and social cognitive career theory.

Over the past 40 years, women have successfully increased their representation in psychology as a discipline. The percentage of women obtaining undergraduate degrees in psychology relative to the total degrees awarded in the field increased from $40.8 \%$ in 1966 to $77.8 \%$ in 2004 (National Science Foundation, Division of Science Resources Statistics [NSF/SRS], 2007). Similarly, the percentage of women earning doctorates in psychology as a percentage of all recipients has also substantially increased, rising from $18.0 \%$ in 1958 to $71.3 \%$ in 2006 (NSF/SRS, 2008). These gains at the undergraduate and graduate levels, however, have not always translated into gains in women's representation as faculty members in departments of psychology. For instance, a study by Kite et al. (2001) showed that women in doctoral departments of counseling psychology composed $80.0 \%$ of the lecturers, $57.5 \%$ of the assistant professors, $39.5 \%$ of the associate professors, and $22.2 \%$ of the full professors. These numbers illustrate a problematic trend for women in many areas of academia, especially in science and engineering: Fewer women occupy each successive level of the academic hierarchy, a phenomenon that has been called "leaks in the career pipeline" (Barinaga, 1992, p. 1367) or an "academic funnel" (Caplan, 1993, p. 22). Researchers have also specifically cited the comparatively low numbers of female versus male full professors as evidence that women have not achieved equality in higher education (Benokraitis, 1998; Caplan, 1993; Hargens \& Long, 2002; Kite et al., 2001), either because they have been denied opportunities to excel or because women, more so than their male counterparts, often must consider other life priorities aside from promotion. With these factors in mind, the goal of this study was to better understand how women associate professors make decisions about pursuing promotion to full professor.

The Counseling Psychologists, Vol. 38, No. 8 (November 2010): pg. 1139-1173. DOI. This article is (C SAGE Publications and permission has been granted for this version to appear in e-Publications@Marquette. Sage Publications does not grant permission for this article to be further copied/distributed or hosted elsewhere without the express permission from SAGE Publications. 
Explanations for the leaky pipeline have focused on external barriers to women's career development. For example, compared with their male colleagues, women academics are less likely to be tenured and less likely to be promoted to full professor, even after controlling for research productivity (Krefting, 2003). In teaching, student evaluations of women faculty are slightly lower than those of male professors of comparable teaching ability, and women must demonstrate more positive teaching qualities in their instruction to be rated equally on their course evaluations by their students (Basow, 1998; Van Giffen, 1990). Women academics often have a larger advising load and spend more time on university and campus committees than their male counterparts do, thus reducing valuable time for research and writing (American Psychological Association [APA] Task Force on Women in Academe, 2000; Chrisler 1998; Fouad \& Carter, 1992; Kite et al., 2001). Because service and advising activities tend to count little in regard to tenure and promotion compared with the publication record (Carter, 1989), the increased time spent on service may be a detriment to women academics seeking full professorship. Women also face a lack of access to mentoring (Coogan \& Chen, 2007; Fouad \& Carter, 1992), the presence of which has been shown to help women stay at their current universities, earn more grant money, and achieve a higher level of promotion (Gardiner, Tiggemann, Kearns, \& Marshall, 2007). All of these discrepancies may be compounded for racial or ethnic minority women, who, relative to their non-Latina White counterparts, are more likely to leave academia and less likely to receive tenure and promotion (APA Commission on Ethnic Minority Recruitment, Retention, and Training in Psychology \& APA Committee on Women in Psychology, 1998).

In addition to challenges within the university, women often carry more responsibility for maintaining a household and raising children than their male colleagues do (Bassett, 2005; Greenglass, 1990; Hochschild, 1989). In a report issued by the Massachusetts Institute of Technology, researchers demonstrated that although most women faculty did not believe that their gender significantly affected their careers, these women did feel that conflicts between family and work were more likely to hinder their careers than to hinder male faculty members' careers (Committee on Women Faculty at the 
Massachusetts Institute of Technology, 1999). Consequently, for some women, domestic variables might further impinge on their ability to be promoted within the academy. What is not yet clear is which, if any, of these factors affect women's decision making about pursuing full professorship.

Additional reasons for the dearth of women at the upper levels of academia may be illuminated in the literature on career theory. In keeping with the majority of qualitative approaches, the goal of this study was not to test which career theory was best in explaining women's decisions about promotion. Instead, as is described by Heppner, Kivlighan, and Wampold (1999), the goal was to allow the participants to explain themselves in an open-ended constructivist manner to allow for data-driven conclusions. This approach contrasts with a positivist, theory-driven approach favored in much quantitative research (Heppner et al., 1999). Setting out to test a particular theory in this study might have resulted in the participants constraining their responses to fit the theory instead of answering in a more authentic manner. With this distinction in mind, it is still important to understand the conclusions of the study within a theoretical framework. Although many career theories were developed to explain male behavior (Cook, Heppner, \& O'Brien, 2002; Swanson \& Fouad, 1999), several theories are applicable to women's career development. Two theories seem particularly applicable: Super's life-span, life-space theory and Lent, Brown, and Hackett's social cognitive career theory (SCCT).

Super's life-span, life-space theory devotes attention to career decisions throughout a lifetime. Super (1990) postulated that people cycle and recycle through stages of career development throughout their lives by mastering specific tasks and that one's career is only one of many roles an individual occupies at any given time in her or his life. The concept of multiple life roles is particularly relevant for many women (as noted above), as they often have significant domestic obligations outside of the workplace (Coogan \& Chen, 2007). Women may also put off other priorities (e.g., children) to obtain an academic job and earn tenure (Halpern, 2004), and some women may choose to de-emphasize their careers in favor of other life roles by not actively pursuing promotion to full professor. In addition, Super's fifth stage of career development, the maintenance stage, might have particular

The Counseling Psychologists, Vol. 38, No. 8 (November 2010): pg. 1139-1173. DOI. This article is @ SAGE Publications and permission has been granted for this version to appear in e-Publications@Marquette. Sage Publications does not grant permission for this article to be further copied/distributed or hosted elsewhere without the express permission from SAGE Publications. 
relevance for women interested in promotion. Super (1990) proposed that individuals in the maintenance stage work to stay competitive and innovative and to avoid stagnation their careers. Clearly, pursuing full professorship would be one means of working toward these maintenance stage goals.

A third theory that has particular relevance for women's career development is SCCT. SCCT was introduced by Lent, Brown, and Hackett in 1994 and uses three interrelated models to explain career interests, career choice behavior, and career performance (Lent, Brown, \& Hackett, 2002). According to the authors of SCCT, career interests develop from a combination of an individual's self-efficacy (i.e., an individual's beliefs about her capability to carry out actions to reach a specific goal) and outcome expectations (i.e., the consequences of performing a particular behavior). The individual's self-efficacy beliefs and outcome expectations can be a product of as many as four factors: personal performance accomplishments, vicarious learning, social persuasion, and physiological states. These four factors are referred to collectively as learning experiences. These learning experiences, in turn, are regulated by personal factors (e.g., race, sex, genetics, and personality) and contextual factors (e.g., socioeconomic status). Once an individual has established her career interests, these interests shape her choice of goals, which in turn shape her choice of action (i.e., career choice behavior). In regard to how well an individual will perform once she enters a given career, her past performance in tasks related to that career will again contribute to her career self-efficacy and outcome expectations. These, in turn, will affect her performance goals, which contribute to her level of performance attainment. For example, consider a recently tenured female associate professor who has a strong publication record (i.e., performance accomplishments), several friends in her department who are full professors (i.e., vicarious learning), strong ties with a mentor who encourages her to pursue promotion (i.e., social persuasion), and time to publish research (i.e., contextual factor). These characteristics, according to SCCT, will create enhanced self-efficacy and positive outcome expectations, thus making this type of individual the most likely to pursue and attain full professorship. SCCT and Super's theory provide a solid framework for understanding the results of this study. 
The goal of this study was to better understand the factors that contribute to women's pursuit of full professorship and to illuminate specific positive and negative critical experiences that affect women's feelings about promotion. Although promotion to full professor is not required to retain an academic job, the underrepresentation of women at the level of full professor is concerning for several reasons. First, promotion to full professor represents the highest possible rank in academia and thus is a sign to one's self and others of having achieved significant professional success. Second, full professorship signifies a position of leadership and influence both nationally and at one's university. The relative paucity of women at this rank may then mean that women have a reduced voice in the affairs of their universities and fields of study (Ceci, Williams, \& Mueller-Johnson, 2006). Third, the lack of women full professors leads to fewer upper level role models for women undergraduate students, graduate students, and junior faculty, perhaps thereby contributing to the lack of mentors, already noted as a problem for women in a variety of careers. Fourth, since promotion to full professor often is accompanied by a salary raise, the underrepresentation of women contributes to the salary discrepancy between male and female academics. For instance, in 2006, women faculty working at doctoral universities earned $78.1 \%$ of the average salary of male faculty, a difference partially accounted for by the greater number of men at full professor (American Association of University Professors, 2007). Thus, more women full professors may lead to more salary equity in the academy.

Given the clear benefits of being a full professor, and the difficulties engendered when fewer women reach this rank, we need to understand what factors contribute to women's decisions to pursue full professorship, a decision-making process that is relatively unexamined in the literature. Consequently, this study sought to understand what factors influence women associate professors' decisions about promotion to full professor. We used a qualitative method, as this approach allowed for a less constrained and more detailed exploration of participants' thinking than would be possible using surveys or other assessment tools. 
NOT THE PUBLISHED VERSION; this is the author's final, peer-reviewed manuscript. The published version may be accessed by following the link in the citation at the bottom of the page.

\section{Method}

\section{Participants}

Twelve tenured women associate professors in APA-approved counseling psychology programs who were geographically dispersed throughout the United States agreed to participate. All of the women had at least some interest in promotion to full professor. Participants who had no interest in promotion were not included in this study. Ten worked at schools classified as "doctoral/research extensive" (i.e., schools where one of the primary missions is producing research), and 2 worked at schools classified as "doctoral/research intensive" (i.e., where research is important but less so than at "extensive" schools; Carnegie Foundation, 2000). Participants ranged in ages from 36 to 61 years $(M=46.8, M d n=44.0, S D=7.7)$. Seven participants identified as Caucasian (meaning non-Latina White), 3 as African American, 1 as Latina, and 1 as Asian. Two participants worked in departments of psychology, and 10 worked in departments of educational psychology; 7 participants served in an administrative role (e.g., training director, department chair) in their departments, and 2 participants had a joint appointment with another department at their universities. Four participants were in the process of applying or preparing to apply soon for full professorship (i.e., within the next 6 months).

Each participant was asked to complete a demographic form regarding the number of years she had served at various academic ranks, how she allocated her time to her professional responsibilities, and her academic accomplishments thus far in her career. These data are shown in Table 1. Participants were also asked to rate the importance of obtaining full professorship, using a scale ranging from 1 (not at all important) to 7 (extremely important). A score of 4 indicated that full professorship was of "moderate importance" to the participant. The results ranged from 2 to $7(M=4.8, M d n=5.0, S D=$ 1.4). Overall, the participants seemed to represent the broad range of activities in which academic psychologists might engage, and a number of the participants had achieved some impressive accomplishments in terms of research, teaching, and professional involvement. 
NOT THE PUBLISHED VERSION; this is the author's final, peer-reviewed manuscript. The published version may be accessed by following the link in the citation at the bottom of the page.

\section{Measures}

In addition to the demographic form described above, participants completed a semistructured interview consisting of four sections (see the appendix). This interview protocol was developed after a review of the literature, extensive discussions with the research team, and consultation with individuals who were knowledgeable about the topic area. These knowledgeable individuals included assistant and associate professors in an APA-approved counseling psychology doctoral program, as well as a full professor with a reputation for her knowledge and writings about career issues for women in the academy. The first section asked about the participants' interest in full professorship, feedback regarding promotion, factors influencing their decision regarding whether to pursue promotion, and the perceived benefits and drawbacks of promotion. The second and third sections asked the participants to describe an incident where they felt encouraged to pursue promotion to full professor and an incident where they felt discouraged to pursue this promotion. The final section asked the participants to describe how their thinking about pursuing full professorship had changed over the course of their careers, their reasons for participating in the study, and the effect of the interview on the participant. At the conclusion of this interview, a follow-up interview was scheduled for approximately 2 weeks after the first interview. The follow-up interview provided the interviewer and participants an additional opportunity to clarify or elaborate on previous statements as well as share thoughts about the first interview.

\section{Procedures}

The interview protocol was piloted with two women academics holding the rank of associate professor who provided feedback to the interviewer regarding the wording, flow, and clarity of the questions. No changes were made to the protocol as a result of the pilot interviews, although the expected time required to participate shown on the recruitment letter was increased from 45 to 60 minutes so that potential participants could make an informed choice.

The Counseling Psychologists, Vol. 38, No. 8 (November 2010): pg. 1139-1173. DOI. This article is (C SAGE Publications and permission has been granted for this version to appear in e-Publications@Marquette. Sage Publications does not grant permission for this article to be further copied/distributed or hosted elsewhere without the express permission from SAGE Publications. 
For recruitment purposes, a list of the names of all women associate professors in counseling psychology was developed by viewing the websites for all 74 APA-approved doctoral programs in counseling psychology (APA, 2003). A total of 66 participants were randomly selected from the list described above. All of these women were solicited for participation through an individually addressed electronic mail that included a brief description of the study, the demographic form, the interview protocol, and a request for participation. Recruiting participants via e-mail and following up with a mailed packet of information has been an effective method of recruiting participants in previous qualitative studies (e.g., Burkard et al., 2006). When an individual indicated an interest in participating in this study, she was sent a complete packet of information via U.S. mail. This packet of information contained the informed-consent letter, the cover letter describing the study in detail, the demographic form, the interview protocol, the follow-up interview protocol, and a postcard for requesting results of the study.

Twelve of the 66 individuals indicated an interest in participating in the study, yielding a response rate of approximately $18 \%$. This represents a stronger participation than the $4 \%$ to $9 \%$ rate that has been achieved in previous qualitative studies that used standard U.S. mail as the primary recruitment technique (e.g., Hill, Nutt-Williams, Heaton, Thompson, \& Rhodes, 1996; Knox, Hess, Williams, \& Hill, 2003; Knox, Schlosser, Pruitt, \& Hill, 2006). All interviews were conducted via telephone and were audio-taped by the principal investigator. The researcher also took notes during the interview in case the tape recorder malfunctioned. A malfunction did occur with one of the interview tapes, and this interview was then reconstructed using the interviewer's notes. This participant was sent the transcript of the reconstructed interview: She agreed that it accurately captured her responses to the questions, and she did not add any further information after reviewing the transcript. All other interviews were transcribed verbatim, except for silences, minimal encouragers, and stutters. All potentially identifying information (e.g., names, institutions, locations, research interests) was deleted, and the audiotapes containing the interviews were erased. The participants' transcripts were identified only by code number, and the key to these code numbers was available only to the primary investigator.

The Counseling Psychologists, Vol. 38, No. 8 (November 2010): pg. 1139-1173. DOI. This article is @ SAGE Publications and permission has been granted for this version to appear in e-Publications@Marquette. Sage Publications does not grant permission for this article to be further copied/distributed or hosted elsewhere without the express permission from SAGE Publications. 
NOT THE PUBLISHED VERSION; this is the author's final, peer-reviewed manuscript. The published version may be accessed by following the link in the citation at the bottom of the page.

\section{Data Analysis}

The data were analyzed using a modified version of consensual qualitative research (CQR; Hill et al., 2005; Hill, Thompson, \& NuttWilliams, 1997). The first three authors (i.e., the primary team) of this article reached consensus regarding all data decisions, and these decisions were then independently reviewed by the auditor (i.e., the fourth author) in the core ideas and cross-analysis stages. During the consensus-building process, team members discussed their differences in understanding the data until each team member agreed with the final decision regarding the placement of data into domains, the content of the core ideas, and the names and content of the crossanalysis categories. When the auditor provided feedback on the core ideas and cross-analysis, the primary team discussed whether to incorporate the suggested changes into the analysis. The CQR methodology was modified to include the use of electronic mail, in addition to the standard phone and in-person discussions, to make decisions about the data, as the primary team found this to be an efficient and effective means to discuss the data. The CQR method is summarized below.

\section{Domain coding}

The interview protocol was used as a foundation for ideas about domain (i.e., topic) titles. Additional domains were added if there was consistent interview content that fell outside of the domains derived from the interview questions, and domains were eliminated if they were unclear or if they were redundant with another domain. All interview transcripts were coded using the same domain list; therefore, if the domain list changed after a transcript had been coded, the previously coded transcripts were recoded to match the updated domain list. This process is used until the data from all cases has been domained. Each domain had a number, and the numbers were assigned to every portion of text across the interviews. The team discussed the assignment of data to domains until agreement was reached. 
NOT THE PUBLISHED VERSION; this is the author's final, peer-reviewed manuscript. The published version may be accessed by following the link in the citation at the bottom of the page.

\section{Core ideas}

In the next step, the interview data (now organized by domain) were reduced to their core ideas or essential elements. In this process, the team tried to capture the essence of what the interviewee had said in as few words as possible without losing any meaning. Once the team came to agreement on the content and wording of the core ideas, the core ideas were sent to the auditor for additional review. The auditor's feedback was reviewed by the primary team, and decisions were made regarding what changes to make in the core ideas.

\section{Cross-analysis}

The core ideas within each domain were compared across cases (i.e., interviews) to look for patterns in the cross-analysis. In addition to identifying patterns, the goal of this stage was to summarize what the participants had discussed in meaningful categories within each domain. The primary team members independently examined the proposed category titles with the corresponding data (i.e., the core ideas) and then offered suggested revisions until consensus was reached. The cross-analysis was then sent to the auditor, who also examined each category title; its core ideas; and the fit between core ideas, categories, and domains. The team reviewed the auditor's feedback and reached consensus regarding what changes to make. The cross-analysis was returned to the auditor for several revisions to ensure that the participants' experiences were adequately captured.

\section{Stability check}

As a validity check, two of the interviews were left out of the initial cross-analysis. Once the analysis was completed, these cases were added to the cross-analysis, and the authors looked to determine whether any new categories emerged and, if so, how many times this occurred. Prior to the addition of the stability cases, there were 46 categories in the cross-analysis. Following the addition of the stability cases, there were 48 total categories, meaning there was only a $2 \%$ increase in the number of categories. Consequently, the results were determined to be stable, meaning that additional interviews were not

The Counseling Psychologists, Vol. 38, No. 8 (November 2010): pg. 1139-1173. DOI. This article is @ SAGE Publications and permission has been granted for this version to appear in e-Publications@Marquette. Sage Publications does not grant permission for this article to be further copied/distributed or hosted elsewhere without the express permission from SAGE Publications. 
deemed necessary to complete this study. After the analyses of the data were completed, the results were sent in manuscript form to the 11 participants who expressed interest in receiving this information. None of these individuals requested changes to the representation of their data.

\section{Author biases}

In standard CQR procedure, the primary team and auditor biases are noted prior to data collection, as they may influence the data analysis and conclusions. In the present study, the biases of the primary team were not collected until after the interviews were completed and two transcripts were domained. In addition, the auditor's biases were not collected; thus, it was unclear as to how her opinions affected the data interpretation. The three primary authors were graduate students and were relatively unfamiliar with the promotion process from associate to full professor or the pressures facing a midcareer academic. Consequently, it was unlikely that the team's biases about this topic would have had a noticeable effect on the data interpretation. The lead author, a man, became interested in this topic due to long-standing interests in gender equality, multicultural issues, and career development. In addition, the lead author had a personal investment in the topic, as he was interested in becoming an academic himself and had a close female family member who was pursuing a nontraditional career in the sciences.

The primary team agreed that most participants would have at least some interest in promotion, as there seemed to be little reason for an individual to completely ignore this opportunity. All primary team members believed that there would be written criteria for promotion at the participants' universities and that participants would talk with their supervisors about pursuing promotion. All primary team members felt that the feedback the participants would receive about full professorship would vary from being encouraging to discouraging, that family obligations would influence whether participants pursued full professorship, that the positive outcomes from obtaining full professorship would be increased earning potential and increased prestige, that the drawback of pursuing promotion would be the time and energy required to improve one's credentials, and that a current 
mentor would assist a participant in attaining promotion. The researchers managed their biases both by self-checking during the analysis and by mentioning to other team members when it was felt that an individual's biases were influencing his or her decision making about the data (e.g., inferring too much meaning from an unclear statement by a participant). This procedure for handling biases is consistent with the approach taken in many other CQR studies (e.g., Burkard et al., 2006; Knox, Burkard, Edwards, Smith, \& Schlosser, 2008; Schlosser, Knox, Moskovitz, \& Hill, 2003).

\section{Results}

The results of this study are presented in three sections. First, the background or contextualized findings regarding participants' thoughts and feelings about full professorship are presented (see Table 2 ). These findings provide a framework within which participants' critical experiences of encouragement and discouragement regarding full professorship can be understood. Next, findings related to participants' encouraging and discouraging experiences regarding full professorship are presented (see Table 3 ). The final section includes illustrative examples of an experience that encouraged pursuit of full professorship and one that discouraged pursuit of full professorship. Consistent with the frequency criteria developed by Hill et al. (2005), categories were labeled general if they applied to all or all but one case (i.e., 11 or 12 cases), typical if they applied to more than half of the cases (i.e., between 7 and 10 cases), and variant if they applied to between 2 and 6, or half, of the cases (i.e., between 2 and 6 cases). Core ideas that emerged in only 1 case were placed into the "other" category for that domain and are not reported here.

\section{Contextual Findings Regarding Full Professorship Requirements for Full Professorship}

Generally, participants reported that they must display excellence in research to obtain full professorship at their universities. Two subcategories emerged under this broad category. First, participants generally felt that such excellence was defined by having a national reputation (one participant described this as a "nondebatable" criterion). In the second subcategory, participants typically stated that

The Counseling Psychologists, Vol. 38, No. 8 (November 2010): pg. 1139-1173. DOI. This article is @ SAGE Publications and permission has been granted for this version to appear in e-Publications@Marquette. Sage Publications does not grant permission for this article to be further copied/distributed or hosted elsewhere without the express permission from SAGE Publications. 
successful applicants for full professor must show a continuous record of publication. One participant, for example, described this criterion as necessary to eliminate applicants who "took a few years off intellectually" after obtaining tenure. In addition to excellence in research, participants also variantly reported that their universities required effective teaching and an excellent record of university service. One participant, for instance, stated, "There's not as much focus on teaching and service [although] your teaching has to be at least average," whereas another stated she had to be "nationally prominent" in service. Finally, participants variantly stated that obtaining external funding (i.e., grants) was an important criterion for full professorship at their universities.

\section{Communication of Requirements}

\section{Means of communication}

Generally, participants indicated that their departments had written criteria for full professorship (e.g., in the faculty handbook). Participants also, however, typically acknowledged the existence of implied (i.e., unwritten) criteria for full professorship that they learned "through the grapevine." For instance, one participant was told by her department chair that she needed to average two post-tenure publications per year, although this requirement was not written in the faculty handbook. Another participant reported that her university increasingly valued external grant funding, and she assumed that she would need to obtain more funding to be a competitive applicant for full professorship, although no one had explicitly told her this criterion.

\section{Quality of communication}

Participants typically reported that the requirements for full professorship were not clearly communicated. As an illustration, one participant commented that her department required her to be "excellent in your area," a criterion she described as "really vague." As another example, several participants indicated that the required publication threshold was not quantified. For those participants who did report a specific number, they indicated that between 20 and 30 publications post-tenure were required. permission has been granted for this version to appear in e-Publications@Marquette. Sage Publications does not grant permission for this article to be further copied/distributed or hosted elsewhere without the express permission from SAGE Publications. 
NOT THE PUBLISHED VERSION; this is the author's final, peer-reviewed manuscript. The published version may be accessed by following the link in the citation at the bottom of the page.

\section{Feedback Received Regarding Pursuit of Full Professorship}

Participants typically received feedback about full professorship from people in their departments or schools. Three subcategories emerged within this broader category. First, participants typically reported that their department chairs gave them feedback about full professorship. For instance, one participant had a department chair who consistently told her, "We need to look at how to get you to get promoted to full professor." Variantly, participants received feedback from either their deans or other colleagues. One participant, for instance, was told by a senior colleague that she had one of the strongest cases he had seen for full professorship because her scholarship and teaching were so integrated. Some participants, however, variantly stated that they had neither received nor asked for any feedback regarding full professorship. One participant, for example, explained that she did not seek feedback "because I don't want anyone to tell me that I can't get it."

\section{Why Pursue Full Professorship?}

In the first broad category, participants generally reported that they intended to pursue full professorship because doing so would personally benefit them in a number of ways. Four subcategories emerged here. In the first and second subcategories, participants generally reported that they would benefit from the raise in salary that comes with promotion and that they would enjoy the increased prestige and satisfaction of knowing that they had achieved the "highest rank" in academia. One participant, for instance, stated that the prestige would be important because it would be an "embarrassment" to be a "stalled associate professor." In a third subcategory, participants variantly stated that they would benefit from the increased power and influence they would have as full professors at their universities. For example, one participant was interested in pursuing full professorship because with that rank she could "piss off anyone I want because they can't get you back." Fourth, participants variantly reported feeling that full professorship would strengthen their credentials for administrative positions. One participant, for instance,

The Counseling Psychologists, Vol. 38, No. 8 (November 2010): pg. 1139-1173. DOI. This article is @ SAGE Publications and permission has been granted for this version to appear in e-Publications@Marquette. Sage Publications does not grant permission for this article to be further copied/distributed or hosted elsewhere without the express permission from SAGE Publications. 
stated that administration jobs were open only to full professors at her university. In responding to the question regarding why they would pursue full professorship, participants also variantly reported that they had always planned to seek this promotion because they had an internal drive to reach the highest level of their profession. For example, one participant stated, "To me it's sort of the completion of one's career. That's where you go, that's where you take it, to the highest level. If you haven't made it there, maybe you haven't accomplished all that you need to." Participants also variantly reported pursuing full professorship so they would be role models to other women. "Somebody's got to do it," remarked one participant. Similarly, another participant felt that, as a woman of color in academia, she had a responsibility to students and faculty in earlier stages of their careers to put herself "out there" as a role model and be successful.

\section{Why Not Pursue Full Professorship?}

Participants identified several factors that inhibited their pursuit of full professorship. Variantly, they reported anxiety about being rejected for full professorship. "It would be hard to work with people if they voted against me," one participant reported. In a second variant category, participants indicated that they had other priorities that made attaining full professorship less important. One participant, for instance, stated that going for full professorship would require the following:

[I would] spend my time doing things that I'm really no longer passionate about and interested in. I mean, I think empirical research is great, but honestly my interests and how I want to make an impact on psychology has moved in different directions.... If I really look and say what is really meaningful to me, that's not where it is.

As a third variant category, participants found that full professorship would decrease their professional mobility because it would be difficult to find a job at a new university at that rank. In addition, participants variantly stated that they had negative experiences going for promotion from assistant to associate professor and that they were wary of having their qualifications evaluated for full professorship. For

The Counseling Psychologists, Vol. 38, No. 8 (November 2010): pg. 1139-1173. DOI. This article is @ SAGE Publications and permission has been granted for this version to appear in e-Publications@Marquette. Sage Publications does not grant permission for this article to be further copied/distributed or hosted elsewhere without the express permission from SAGE Publications. 
instance, one participant described some of the people in her department as "vindictive and evil" and felt that she would be taking an emotional risk if she were to apply for full professorship. Another participant described the politics of academic promotion as "petty" and did not care for her "less-than-collegial treatment" during the tenure process. After eventually earning tenure, she felt her experience was "so miserable that I squashed all discussion of promotion." In a fifth variant category, some women felt that there were no drawbacks to pursuing or becoming a full professor. "If I don't get it, you know the world will keep turning, and I will keep getting a paycheck," remarked one participant.

\section{What Would Change Participants' Minds About Full Professorship?}

Typically, nothing would change participants' minds about pursuing full professorship. "I will plod along until I get there," stated one participant. Another participant remarked,

It's something I clearly want and clearly have in mind, and I know I can do it, even if I have to wait a couple years and get some of this research out of the drawers and into the pipeline.

Variantly, however, participants stated that if they were told that they would not be able to achieve promotion, they would not apply. For instance, one participant indicated that she would "talk to different higher-ups and get them to give me feedback on my credentials, and if it wasn't strongly unanimous that things should be fine, I would probably hesitate." Finally, participants variantly indicated that they might change their minds about pursuing full professorship if the administration at their universities changed. "There's [are] some counseling psych departments in schools of education that have been closed and have been butchered basically. So it depends on if we're around or not."

The Counseling Psychologists, Vol. 38, No. 8 (November 2010): pg. 1139-1173. DOI. This article is @ SAGE Publications and permission has been granted for this version to appear in e-Publications@Marquette. Sage Publications does not grant permission for this article to be further copied/distributed or hosted elsewhere without the express permission from SAGE Publications. 


\section{Current Mentoring With Regard to Pursuit of Full Professorship}

Typically, participants reported that they were not currently being mentored in pursuing full professorship. One participant explained that nobody at her university has time to mentor her because "everyone is so busy trying to get their own work done." One subcategory emerged where participants variantly reported that the lack of such mentorship had negatively affected their career progress. One participant explained,

I think if I had had a mentor I would have gone up [for promotion for full professorship] last year as well because I would have published more. I would've had more of a national reputation. Lacking that, I've been a little bit slower in reaching the point where I'm clearly qualified.

Alternatively, participants variantly stated that they had current mentors and that their mentors encouraged pursuit of full professorship. One participant's mentor expected her to "go to the top," whereas another remarked that her mentors made full professorship seem like "sort of what you do." Women who reported current mentoring averaged more published peer-reviewed articles (17.0 vs. 15.7) and more total publications (27.8 vs. 21.9) than those who did not have current mentoring.

\section{Critical Experiences}

Participants were asked to describe a critical experience that had encouraged their pursuit of full professorship and then to describe an experience that discouraged their pursuit of full professorship. Nine of 12 participants reported an encouraging critical experience. The women who reported having an encouraging critical experience averaged more peer-reviewed publications (16.0 vs. 11.0) and more total publications (26.2 vs. 16.6) than those who did not have an encouraging critical experience. All 12 participants reported a discouraging critical experience. 


\section{Encouraging Critical Experience}

\section{Description}

Participants variantly stated that they received feedback that they should apply for full professorship (e.g., from dean, department chair, fellow academics). In a second variant category, participants stated that they had published notable research, which caused them to reevaluate the possibility of full professorship. For example, one participant stated that she had published "fun and impactful research about which she also received positive feedback. Another participant, who had published a notable article early in her career, indicated that she was flattered that students and other faculty whom she had never met would approach her at conferences and want to discuss her work.

\section{Effect of experience}

Generally, as would be expected, these experiences encouraged participants to seek full professorship. One participant, for instance, talked about comments that her dean made during a department meeting acknowledging that there were very few women or people of color at the level of full professor or in administration. The participant, a woman of color, described the effect of the meeting: "I went back to my office and did some thinking.... Maybe it is important for me to do this [promotion], not just for myself but for more of the symbolism that it represents." Another participant who had already planned to seek full professorship significantly accelerated her time line after receiving support from her dean. Participants also variantly indicated that the encouraging experience helped them value their work or increased their self-esteem. For example, one participant who received encouragement from her dean to go for promotion stated, "There really isn't a lot of individual recognition [in the department], [so] I think in some ways my self-esteem increased... . That [encouraging feedback] was unanticipated and unexpected, and nicely accepted." 


\section{Discouraging Critical Experience}

\section{Description}

Variantly, participants described feeling discriminated against due to their gender, sexual orientation, or research program. One participant, who described herself as a "double minority" in terms of race and sex at her university, felt that she was being punished for being a nonmajority person when she was initially voted down for tenure. Another participant described how a university administrator informed the entire faculty that grant activity and quantitative research would be weighted more heavily than qualitative research in tenure and promotion decisions. The participant, who identified herself as a qualitative researcher, felt the administrator was dismissing her academic work and her contributions to the university. In a second variant category, participants stated that they faced a conflict between their family and career interests. For example, one participant talked about her desire to spend time with her children as taking time away from her research and publishing and thus delaying her pursuit of full professorship.

\section{Effect of experience}

Typically, participants reported that the discouraging critical experience made them doubt their qualifications for full professorship. One participant, who was told that she was considering full professorship prematurely, felt that the remarks challenged her perception of her qualifications. She wondered if she was being overconfident about her vita or if she was being held to a higher standard because she was a person of color:

I think many of us [women of color] have been socialized sometimes to have that imposter syndrome. To have that feeling of how we're really not supposed to be where we're at. So, I think any kind of challenge, even if it's a poorly evidenced challenge, sometimes causes me to wonder if other people have that question ... and think that I'm being overly confident. 
In a variant category, participants reported feeling discouraged about seeking full professorship after the incident. One participant, who was initially denied tenure, told her department chair at the time, "You'll never have to worry about seeing my paperwork again." Participants also variantly reported that the experience made them angry with or feel rejected by their colleagues. One individual, whose use of qualitative methodology was dismissed by a colleague, stated that she was "pissed off" and demoralized by his comments. Another participant, whose negative critical experience involved difficulty with the initial tenure process, stated that the whole incident made her feel like a "duck out of water" and that she should "go someplace else." Finally, participants variantly reported that they were able to put the discouraging experience in perspective. For instance, one participant who had experienced sex discrimination in the past stated, "I think it's in the past. I don't think there is any long-term effect at this point." Another participant responded to the criticism she received from fellow faculty members by saying to herself that "a good therapist knows how to cognitively reframe all of that, so I was able to put that into perspective and not really internalize it."

\section{Illustrative Examples of Encouraging and Discouraging Critical Experiences}

Below are examples of encouraging and discouraging critical experiences reported by 2 participants. These examples were selected to speak to the complexities of an individual's decision making about promotion and are not intended to represent all of the participants' experiences. Different participants were selected to represent each of these experiences, and the examples have been altered to protect confidentiality.

\section{Encouraging Critical Experience}

The participant was a 42-year-old Caucasian woman in a counseling psychology program in a school of education. In addition to obtaining full professorship, this participant was interested in an administrative job so she could be of assistance to other women at the university. The criteria for promotion to full professorship were written in the faculty handbook at her university, and she reported that these permission has been granted for this version to appear in e-Publications@Marquette. Sage Publications does not grant permission for this article to be further copied/distributed or hosted elsewhere without the express permission from SAGE Publications. 
requirements emphasized excellence in research, teaching, and service (none of which, she noted, were defined). This participant felt that her qualifications compared very well with what was required by her university for successful promotion to full professorship, and she had received supportive feedback from her dean, colleagues, and other administrators (e.g., she was told that "there wouldn't be any problem" with her application). When this participant became an associate professor, she was initially not interested in full professorship until several women full professors at her university changed her mind by telling her that she would be a role model to women junior faculty and students. She felt that the only reason she was considering full professorship was because it would validate the support these women had provided. This participant never had a mentor who was a woman full professor in her field, and she felt that because of this absence, she missed an opportunity to see how another woman made choices about balancing work, family, and community obligations.

The encouraging critical experience occurred 1 year prior to participating in this study, when the participant was having a casual conversation in the hallway with the dean of her program. The dean, whom the participant described as not a "terribly warm person, and not very supportive," asked her if she was considering applying for full professorship. The participant responded that she "hadn't really thought about it." The dean was "very, very encouraging" of her application and told her that "[you] need to do this." She was very surprised by the feedback and felt it led to a reevaluation of her priorities as a faculty member. She was also very pleased to be noticed for her individual achievements because her department is very "team oriented" and uses "a lot of 'we' language." Not surprisingly, she felt that this experience strongly encouraged her to apply for full professor.

\section{Discouraging Critical Experience}

This participant was a 54-year-old Caucasian associate professor of counseling psychology in a school of education. Obtaining full professorship had not been a long-term goal for this participant, aside from the fact that she had planned to apply when she had "enough publications." She indicated that national reputation and prolonged

The Counseling Psychologists, Vol. 38, No. 8 (November 2010): pg. 1139-1173. DOI. This article is @ SAGE Publications and permission has been granted for this version to appear in e-Publications@Marquette. Sage Publications does not grant permission for this article to be further copied/distributed or hosted elsewhere without the express permission from SAGE Publications. 
scholarship were important qualifications at her university (although she stated that these were vaguely defined in the written guidelines). Her dean told her that most successful applicants for full professorship had at least 25 journal publications, although this benchmark was also not listed in the guidelines. The participant reported that her main motivation for applying for full professorship would be to obtain a raise in her salary, acquire the additional prestige associated with being full professorship, and be able to vote on other full professorship applications so she could ensure that they received fair treatment. She did not have a current mentor and felt that this negatively affected her career and her progress toward applying for promotion.

The participant was initially voted down for tenure in her department, despite having multiple first-author publications and the support of her chair and dean. She felt that she was discriminated against because of she was "an uppity woman" who did not ingratiate herself to powerful people in the department. She was even more mystified by the vote because another person in the department who had fewer publications than this participant "sailed through" with unanimous support. The participant stated,

It totally blindsided me, and it made it very, very difficult to go to work because I had to look at people. I mean I couldn't spit on them. I had to look people in the eye. I had to talk to them. I had to be in meetings with them. I had to sit on committees with them, and I knew exactly who had stabbed me in the back.

Eventually, the university tenure and promotion committee overruled the department vote, and this participant was awarded tenure. Afterward, the individuals who had voted against the participant stopped talking to her and were "extremely resentful" because they thought they had successfully "shoved" the participant out of the department. She, however, refused to leave, and it took years before some of the people in the department could talk with the participant without "gritting their teeth." The participant was interested in promotion to full professorship; however, in applying for such a promotion, she felt she would be taking an emotional risk because "it is reasonably likely [that] they will sabotage me again," which would be "very upsetting." She had been waiting to build her qualifications so that these faculty members would not have any "legitimate excuse" to

The Counseling Psychologists, Vol. 38, No. 8 (November 2010): pg. 1139-1173. DOI. This article is C SAGE Publications and permission has been granted for this version to appear in e-Publications@Marquette. Sage Publications does not grant permission for this article to be further copied/distributed or hosted elsewhere without the express permission from SAGE Publications. 
vote against her. Consequently, she was waiting to apply for promotion so that she could be absolutely sure that she would not be denied.

\section{Discussion}

Based on these findings, several factors appear to affect women's pursuit of full professorship. Specifically, women who had mentors, received encouraging feedback from colleagues, and published notable research described these experiences as encouraging their pursuit of full professorship. In contrast, women who did not have a current mentor, felt discriminated against, had negative tenure and promotion outcomes, felt that their research was undervalued, or experienced career and family conflicts reported that these experiences decreased their interest in full professorship or their perception of their ability to achieve this goal.

\section{Contextual Findings Regarding FP}

Consistent with Carter's 1989 study on the promotion requirements in academia, these participants reported that excellence in research (e.g., national reputation, publication record) was necessary to obtain full professorship. The heavy emphasis on research and publication verified that many universities, especially the research-extensive and -intensive institutions from which the participants were recruited, highly value the production and publication of research as a hallmark of excellence in the profession. Consequently, participants' perceptions of their research and publication records were, unsurprisingly, quite important in determining if and when they applied for full professorship.

Although most participants acknowledged that they had received vague written guidelines regarding the criteria for full professorship, many also had to look beyond such guidelines to unwritten (i.e., implied) criteria to gain further clarification (e.g., number of publications required). The apparent lack of specificity in the criteria for full professorship is consistent with previous research on tenure (Sorcinelli, 1994). To gain such clarification, then, many participants spoke with other academics, especially department chairs permission has been granted for this version to appear in e-Publications@Marquette. Sage Publications does not grant permission for this article to be further copied/distributed or hosted elsewhere without the express permission from SAGE Publications. 
and deans, whose feedback, in light of the unclear written criteria, carried substantial weight. Thus, women in departments with supportive chairs and deans may have an advantage over those in less supportive environments, as the former may be better able to learn what full professorship requires and thus may have a better chance at attaining full professorship. One helpful remedy that might encourage more full professorship applications by women, then, might be to define terms such as excellence and national reputation, which would eliminate some of the subjectivity in the promotion guidelines.

Almost all of the participants identified an increase in salary and prestige as the main benefits of full professorship, and it was clear that these benefits partially motivated their desire for promotion. What was not clear was how strongly these variables motivated the participants. Previous research has shown that men value the ability to make more money during their careers. Women, on the other hand, value working with people and contributing to society (Duffy \& Sedlacek, 2007), and as they progress through their careers, women place more emphasis on "balance" and less on "challenge" or "moving up the ladder" (Cabrera, 2007, p. 229). Although the women in this study reported a desire to make more money and acquire more prestige, these variables might not be as motivating for women as for men. If so, perhaps emphasizing the communal benefits of being a role model and helping the university would encourage more women to actively pursue promotion. Alternatively, it is possible that the participants felt that money and prestige were quite motivating, which would mean that the perceived benefits of full professorship do not explain the discrepancy between men's and women's attainment of this rank.

One potential pathway for navigating obstacles in the promotion process is the support of a mentor. The majority of women in this study reported that they lacked a current mentor, with some asserting that this absence had hurt their career development. In contrast, a minority of participants did have a current mentor, and they felt this support significantly aided their pursuit of promotion. The participants' assessment of the affect of mentors on their success was supported quantitatively as well, with the mentored participants reporting more peer-reviewed publications and total publications than the nonmentored participants did. These findings add support to Fouad

The Counseling Psychologists, Vol. 38, No. 8 (November 2010): pg. 1139-1173. DOI. This article is @ SAGE Publications and permission has been granted for this version to appear in e-Publications@Marquette. Sage Publications does not grant permission for this article to be further copied/distributed or hosted elsewhere without the express permission from SAGE Publications. 
and Carter's (1992) statement that a mentor is a "critical factor in an individual's success" (p. 127), especially given that the women who did have mentors reported that such individuals encouraged their pursuit of full professorship. Perhaps it is unfair to expect that all women academics would have mentors at this stage in their careers; however, where these mentors were present, they clearly made a difference.

\section{Critical Experiences Regarding Full Professorship}

Most participants were able to describe an experience that encouraged their pursuit of full professorship, and most of these experiences involved receiving supportive feedback from other academics about their research (e.g., publishing a noteworthy journal article) or about their record of accomplishments. This supportive feedback usually came from colleagues or supervisors, clearly indicating the importance of informal encouragement regarding promotion. Thus, one possible reason for the dearth of women full professors is that they are not receiving needed encouragement and support to continue advancing in their careers. In other words, some women academics may be working in a "null environment" (Freeman, 1979), which neither encourages nor discourages individuals but may result in harm to women due to "differences in familial, peer, and societal support for career pursuits" (p. 221). Betz (1989) elaborated on this argument by saying that the lack of encouragement for women to pursue nontraditional career goals (e.g., full professorship) essentially results in a covertly unsupportive, and thus subtly discouraging, environment. In support of this idea, 3 participants did not report an encouraging critical experience. All 3 of these women reported that they had no current mentorship regarding full professorship, that their qualifications did not meet their universities' requirements for full professorship, and that the requirements for full professorship were unclear. Furthermore, these participants averaged fewer peer-reviewed publications and fewer total publications than the women who did have an encouraging critical experience. It is possible that these women truly were not qualified for promotion, that they did not seek addition clarification of the promotion criteria, and that they had not tried to find mentors. It is also possible, however, that no one had taken the time to give these participants feedback, clarify the

The Counseling Psychologists, Vol. 38, No. 8 (November 2010): pg. 1139-1173. DOI. This article is @ SAGE Publications and permission has been granted for this version to appear in e-Publications@Marquette. Sage Publications does not grant permission for this article to be further copied/distributed or hosted elsewhere without the express permission from SAGE Publications. 
promotion criteria, help them find mentors, or meaningfully encourage their scholarship, thus explaining their lack of an encouraging critical experience. Consequently, it may not be enough for chairs and deans to assume that faculty members will accurately evaluate their own vitas and apply for promotion when ready; those in such administrative roles may need to be more proactive and overtly supportive, especially for women faculty.

In contrast to the encouraging experience wherein $25 \%$ of the sample could not recall an event that bolstered the pursuit of full professorship, all participants reported having at least one experience that discouraged their efforts toward promotion. The types of experiences fell into two main categories. First, some women reported that they felt discriminated against by their colleagues either for the type of research they did (e.g., qualitative) or because they were not a White heterosexual male (e.g., woman, person of color, lesbian). Given that research and publications are highly valued in applying for full professorship, having one's research dismissed by colleagues was understandably very discouraging, although perhaps not as destructive as being treated unfairly based on one's gender, race, or sexual identity. Such discouraging experiences indicate that although the academic climate for women in psychology may have improved in many ways (e.g., they exist in greater numbers now than they did before), overt discrimination still occurs, meaning that some underrepresented groups might have difficulty being promoted regardless of the strength of their qualifications or how much they believe they should succeed. These negative experiences, however, did not completely dissuade these participants from their pursuit of full professorship, suggesting that resilience may play an important role in the promotion process. In fact, some theorists have argued that resilience and hardiness in the face of obstacles are essential for career success (London, 1998). The resilience of some participants in this study is visible in the responses of the women who reported that they were able to put their negative experiences in perspective over time or who planned to apply for promotion despite experiencing discrimination.

The second type of discouraging critical experiences involved making difficult choices about career versus family priorities. This

The Counseling Psychologists, Vol. 38, No. 8 (November 2010): pg. 1139-1173. DOI. This article is @ SAGE Publications and permission has been granted for this version to appear in e-Publications@Marquette. Sage Publications does not grant permission for this article to be further copied/distributed or hosted elsewhere without the express permission from SAGE Publications. 
conflict between individualistic career goals and nurturing family relationships has been emphasized consistently in the women's career development literature (Farley, 1970; Gilligan, 1982; Hochschild, 1989) and is also consistent with a 1999 Massachusetts Institute of Technology report indicating that women faculty were more likely than male faculty to feel that family responsibilities, such as being the primary caretaker for children, hurt their careers (Committee on Women Faculty at the Massachusetts Institute of Technology, 1999). Consequently, anything that colleges and universities can do to minimize these conflicts (e.g., mentoring to provide guidance on how to navigate these issues; onsite daycare; flextime) would likely help women achieve more success in the academy, as women continue to shoulder disproportionate domestic responsibilities compared to their male counterparts.

\section{Theoretical Applications}

Donald Super's life-span, life-space theory offers a framework for the study's findings. Specifically, his concept of "life space," or the importance of other life roles in addition to one's career, clearly emerged within these results. According to this theory, the importance that one places on various life roles affects a person's interests and decisions about career opportunities. In this study, several participants reported that they had other life priorities (e.g., spending time with family) that were more important than pursuing full professorship. Unfortunately, the observation that women may have other life roles outside of career obligations does not necessarily explain the process of how a person assigns value to each life role, nor does it allow for a meaningful explanation for why some women do attain promotion to full professorship, whereas others do not. Thus, although Super's theory recognizes the often competing life roles women academics inhabit, it does not illuminate how they make decisions regarding the relative importance of each such role. In addition, most of the participants said they would keep trying for full professorship until they are qualified, an idea that fits well with Super's (1990) maintenance stage. It is also possible, however, that women associate professors who are not interested in promotion have found other ways to complete the maintenance stage tasks in ways that are less rewarded by the academic system (e.g., providing psychotherapy, 
university service). Overall, then, Super's theory, although helpful, does not provide the guidance that is needed to understand women seeking promotion.

SCCT appears to provide the best framework for understanding the results. As previously discussed, SCCT posits that an individual's self-efficacy and outcome expectations (i.e., the consequences of performing a particular behavior) are critical in career decision making. Self-efficacy beliefs and outcome expectations are a product of four factors: personal performance accomplishments, vicarious learning, social persuasion, and physiological states. All four of these factors were discussed by participants in this study. Personal performance accomplishments were mentioned both as a reason to pursue and not to pursue full professorship, as when participants said they would apply for full professorship when they felt their credentials were sufficient and that publishing notable research encouraged their pursuit of full professorship. Second, vicarious learning was also important to participants. Specifically, several participants indicated that having a role model who had attained full professorship encouraged them to pursue full professorship, even without the model needing to discuss that idea with the participant. Third, participants discussed the positive and negative effects of social persuasion. For example, several participants discussed how encouraging feedback about full professorship positively affected their perceptions of their credentials and encouraged their pursuit of full professorship, whereas others indicated that discrimination or having one's research undervalued by peers negatively affected their perceptions of their qualifications and discouraged pursuit of full professorship. Finally, some participants also reported that physiological factors (e.g., anxiety) affected their decisions about pursuing promotion.

Consistent with SCCT, participants reported that one outcome of the encouraging critical experience was that they increasingly valued themselves or their work (i.e., improved self-efficacy). In contrast, many participants doubted their qualifications for full professorship after the discouraging critical experience (i.e., lowered self-esteem and outcome expectations). Self-efficacy may be additionally important for pursuit of full professorship because the performance criteria necessary to obtain promotion were vague, thus leaving participants to

The Counseling Psychologists, Vol. 38, No. 8 (November 2010): pg. 1139-1173. DOI. This article is @ SAGE Publications and permission has been granted for this version to appear in e-Publications@Marquette. Sage Publications does not grant permission for this article to be further copied/distributed or hosted elsewhere without the express permission from SAGE Publications. 
NOT THE PUBLISHED VERSION; this is the author's final, peer-reviewed manuscript. The published version may be accessed by following the link in the citation at the bottom of the page.

rely on their own sense of themselves and their qualifications regarding whether to actively pursue promotion. Overall, the results of this study suggest that SCCT provides a superior explanatory model for how women pursue full professorship than do other theories commonly advanced to understand women's career development.

\section{Limitations}

A modified version of CQR was used in this study. The modification was the use of e-mail to discuss and analyze the data, in addition to in-person and phone conversations. Although e-mail allowed the research team to communicate efficiently, this approach may have altered the way in which decisions were made about the data, because e-mail limits the spontaneous back-and-forth and immediate conversations that occur over the phone or in-person. A second potential limitation is that the lead author was a male graduate student who interviewed women academics. The women who participated in this study may have disclosed more had they been talking to a woman or an academic. It is also possible, of course, that some participants disclosed more in talking with a graduate student instead of an academic because they may have considered him more removed from their peer group and not in competition with them. Third, the results in this study may not be generalizable to all women associate professors of counseling psychology. Finally, this study only captured the experiences of women in academia who were at least somewhat interested in pursuing full professorship (i.e., scoring at least a 2 out of 7 on the "importance of obtaining full professorship" scale from the demographic form). Women who definitively did not want to pursue full professorship were not interviewed and neither were male associate professors interested in promotion. It is possible that women who were definitively not interested in promotion may have as much, if not more, to share about their experiences compared with their colleagues interested in full professorship. Similarly, a study of men interested in promotion could provide further insight on how the perspectives of male and female faculty overlap and differ.

The Counseling Psychologists, Vol. 38, No. 8 (November 2010): pg. 1139-1173. DOI. This article is @ SAGE Publications and permission has been granted for this version to appear in e-Publications@Marquette. Sage Publications does not grant permission for this article to be further copied/distributed or hosted elsewhere without the express permission from SAGE Publications. 
NOT THE PUBLISHED VERSION; this is the author's final, peer-reviewed manuscript. The published version may be accessed by following the link in the citation at the bottom of the page.

\section{Implications}

The results of this study have several implications for women associate professors in counseling psychology. First, most of the women in this study indicated that they had a professional goal of achieving full professorship and that nothing was going to change their minds about this pursuit, a finding that indicates a strong interest in full professorship. Because many women in psychology, however, never achieve this rank, the profession needs to find ways to aid women in achieving promotion. For instance, the supervisors (e.g., chairs, deans) of women associate professors might play a role in helping or hindering the full professorship process, as their feedback might encourage women to pursue this rank by helping them overcome evaluation anxiety and self-doubt. Supervisors may also be of assistance by ensuring that their faculty members' ability to publish noteworthy research is maximized, given the apparent importance of such work in attaining promotion. Departments and universities may also help applicants pursuing full professorship by providing clear and precise promotion criteria to remove some of the uncertainty from this process. For instance, the procedural model for tenure and promotion, where an individual's accomplishments are scored by using a standardized matrix, would likely reduce bias and increase transparency. Some have been critical of the procedural model, as it reduces the role of the judgment of one's peers in the tenure and promotion process (Matusov \& Hampel, 2008); however, clear guidelines may help ensure that personal politics or overt discrimination do not interfere with promoting qualified applicants. Finally, aiding women, particularly women of color, in finding mentors might be a way to increase their chances of attaining promotion, a finding supported by other research and career theory (Coogan \& Chen, 2007; Fouad \& Carter, 1992; Gardiner et al., 2007). Thus, in addition to the benefits to women, colleges and universities would likely benefit from such mentoring relationships by creating a more equal environment for women and by having a more diverse group of people at the top level of the academy. permission has been granted for this version to appear in e-Publications@Marquette. Sage Publications does not grant permission for this article to be further copied/distributed or hosted elsewhere without the express permission from SAGE Publications. 
NOT THE PUBLISHED VERSION; this is the author's final, peer-reviewed manuscript. The published version may be accessed by following the link in the citation at the bottom of the page.

\section{Future Research}

There are several possible directions for future research. First, researchers could use qualitative or quantitative methods to explore how these participants' experiences compare with those of women in clinical psychology as well as with those of women in other disciplines (e.g., anthropology, chemistry, foreign languages). Cross-discipline differences could reveal specific factors at play within particular fields, and knowledge of these specifics could allow appropriate and accurate adjustments to policy. Second, researchers could study male associate professors in counseling psychology to determine if there are differences between the sexes regarding the pursuit of full professorship. Such research could illuminate differences between how men and women view promotion and thus could further explain why there are many more men than women at the top levels of the academy. Third, this research could be extended to women seeking promotion to administrative positions (e.g., dean), where women are even less represented than they are at the level of full professor (Caplan, 1993). Such an understanding might help colleges and universities find a way to recruit more women into those positions. Fourth, future researchers could explore the written copies of the retention, promotion, and tenure guidelines and determine how they vary by university. These guidelines could also be examined for their clarity and specificity, as many women in this study reported that the lack of specificity was a concern and may be an obstacle to promotion. Finally, future research should incorporate SCCT, as this approach appears to offer the best theoretical framework for understanding women's decisions about promotion.

\section{Conclusion}

The importance of women seeking full professorship in psychology has been discussed by former APA president Dr. Diane Halpern, who attributed the dearth of women full professors partially to "few choices in academe for managing the multiple demands of work and family" (Halpern, 2004, p. 5). She referred to women's attainment of full professorship as a "civil rights issue," suggested that the academic tenure and promotion system was "outdated [and] flawed," and encouraged psychologists to think in creative ways about permission has been granted for this version to appear in e-Publications@Marquette. Sage Publications does not grant permission for this article to be further copied/distributed or hosted elsewhere without the express permission from SAGE Publications. 
how to assist women in achieving promotion and tenure (e.g., parttime tenure-track jobs). In keeping with Halpern's comments, if the field is to make progress on the retention and advancement of women faculty, further efforts to improve the promotion possibilities for women in academia are imperative.

\section{Notes}

${ }^{1}$ Marquette University, Milwaukee, WI, USA

${ }^{2}$ Loyola University, Baltimore, MA

${ }^{3}$ Private practice, Madison, Wisconsin

\section{Corresponding Author:}

- Nathan T. Pruitt, Holthusen Hall, Room 204, 1324 W. Wisconsin Avenue, P.O. Box 1881, Milwaukee, WI, 53201-1881. Email: nathan.pruitt@marquette.edu

\section{Acknowledgements}

- We thank April Schaack for transcribing the interviews. We also thank Alan Burkard, Lisa Edwards, Tim Melchert, and Nadya Fouad for their comments on earlier drafts of this article.

\section{Declaration of Conflicting Interests}

- The authors declared no potential conflicts of interests with respect to the authorship and/or publication of this article.

\section{Funding}

- The authors received no financial support for the research and/or authorship of this article.

\section{Bios}

- Nathan T. Pruitt received his doctorate in Counseling Psychology at Marquette University. He is a psychologist at the Marquette University Counseling Center.

- Adanna J. Johnson received her doctorate in Counseling Psychology at Marquette University. She works as an assistant professor in the Department of Psychology at Loyola University in Maryland.

- Lynn Catlin received her doctorate in Counseling Psychology at Marquette University. She is a psychologist in private practice in Madison, Wisconsin.

The Counseling Psychologists, Vol. 38, No. 8 (November 2010): pg. 1139-1173. DOI. This article is @ SAGE Publications and permission has been granted for this version to appear in e-Publications@Marquette. Sage Publications does not grant permission for this article to be further copied/distributed or hosted elsewhere without the express permission from SAGE Publications. 
NOT THE PUBLISHED VERSION; this is the author's final, peer-reviewed manuscript. The published version may be accessed by following the link in the citation at the bottom of the page.

- Sarah Knox received her PhD in Counseling Psychology at the University of Maryland. She is an associate professor in the Department of Counselor Education and Counseling Psychology at Marquette University.

\section{References}

American Association of University Professors. (2007). AAUP faculty gender equity indicators 2006. Retrieved October, 2009, from http://www.aaup.org/AAUP/pubsres/research/geneq2006.htm

American Psychological Association. (2003). Accredited programs in counseling psychology. Retrieved October 3, 2003, from http://www.apa.org/ed/accreditation/counspsy.html

American Psychological Association Commission on Ethnic Minority Recruitment, Retention, and Training in Psychology \& American Psychological Association Committee on Women in Psychology. (1998). Surviving and thriving in academia: A guide for women and ethnic minorities. Washington, DC: American Psychological Association.

American Psychological Association Task Force on Women in Academe. (2000). Women in academe: Two steps forward, one step back. Washington DC: American Psychological Association.

Barinaga, M. (1992). Profile of a field: Neuroscience-The pipeline is leaking. Science, 255(5050), 1366-1367.

Basow, S. A. (1998). Student evaluations: The role of gender bias and teaching styles. In L. H. Collins, J. C. Chrisler, \& Quina, K. (Eds.), Career strategies for women in academe: Arming Athena (pp. 135156). Thousand Oaks, CA: Sage.

Bassett, R. H. (Ed.). (2005). Parenting and professing: Balancing work with an academic career. Nashville, TN: Vanderbilt University Press.

Benokraitis, N. V. (1998). Working in the ivory basement: Subtle sex discrimination in higher education. In L. H. Collins, J. C. Chrisler, \& Quina, K. (Eds.), Career strategies for women in academe: Arming Athena (pp. 135-156). Thousand Oaks, CA: Sage.

Betz, N. E. (1989). Implications of the null environment hypothesis for women's career development and for counseling psychology. The Counseling Psychologist, 17, 136-146.

Burkard, A. W., Johnson, A. J., Madson, M., Pruitt, N. T., Contrares-Tadych, D., Kozlowski, J., et al. (2006). Supervisor cultural responsiveness and unresponsiveness in cross-cultural supervision. Journal of Counseling Psychology, 53, 288-301.

Cabrera, E. F. (2007). Opting out and opting in: Understanding the complexities of women's career transitions. Career Development International, 12, 218-237.

The Counseling Psychologists, Vol. 38, No. 8 (November 2010): pg. 1139-1173. DOI. This article is (C SAGE Publications and permission has been granted for this version to appear in e-Publications@Marquette. Sage Publications does not grant permission for this article to be further copied/distributed or hosted elsewhere without the express permission from SAGE Publications. 
NOT THE PUBLISHED VERSION; this is the author's final, peer-reviewed manuscript. The published version may be

accessed by following the link in the citation at the bottom of the page.

Caplan, P. J. (1993). Lifting a ton of feathers: A woman's guide for surviving in the academic world. Toronto, Canada: University of Toronto Press.

Carnegie Foundation. (2000). Carnegie classification of higher education. Retrieved November 15, 2005, from http://chronicle.com/stats/carnegie/\#definitions

Carter, R. E. (1989). Comparison of criteria for academic promotion of medical-school and university-based psychologists. Professional Psychology: Research and Practice, 20, 400-403.

Ceci, S. J., Williams, W. M., \& Mueller-Johnson, K. (2006). Is tenure justified? An experimental study of faculty beliefs about tenure, promotion, and academic freedom. Behavioral and Brain Sciences, 29, 553-569.

Chrisler, J. C. (1998). Women as faculty leaders. In L. H. Collins, J. C. Chrisler, \& K. Quina (Eds.), Career strategies for women in academe: Arming Athena (pp. 107-134). Thousand Oaks, CA: Sage.

Committee on Women Faculty at the Massachusetts Institute of Technology. (1999). A study on the status of women faculty in science at MIT. MIT Faculty Newsletter XI(4).

Coogan, P. A., \& Chen, C. P. (2007). Career development and counseling for women: Connecting theories to practice. Counseling Psychology Quarterly, 20, 191-204.

Cook, E., Heppner, M., \& O'Brien, K. (2002). Career development of women of color and White women: Assumptions, conceptualizations, and interventions from an ecological perspective. Career Development Quarterly, 50, 291-305.

Duffy, R. D., \& Sedlacek, W. E. (2007). What is most important to students' long-term career choices: Analyzing 10-year trends and group differences. Journal of Career Development, 34, 149-163.

Farley, J. (1970). Graduate women: Career aspirations and desired family size. American Psychologist, 25, 1099-1100.

Fouad, N. A., \& Carter, R. T. (1992). Gender and racial issues for new counseling psychologists in academia. The Counseling Psychologist, 20, $123-140$.

Freeman, J. (1979). Women: A feminist perspective (2nd ed.). Palo Alto, CA: Mayfield.

Gardiner, M., Tiggemann, M., Kearns, H., \& Marshall, K. (2007). Show me the money! An empirical analysis of mentoring outcomes for women in academia. Higher Education Research and Development, 26, 425-442.

Gilligan, C. (1982). In a different voice: Psychological theory and women's development. Cambridge, MA: Harvard University Press.

Greenglass, E. R. (1990). Type A behavior, career aspirations, and role conflict in professional women. Journal of Social Behavior and Personality, 5, 307-322.

The Counseling Psychologists, Vol. 38, No. 8 (November 2010): pg. 1139-1173. DOI. This article is @ SAGE Publications and permission has been granted for this version to appear in e-Publications@Marquette. Sage Publications does not grant permission for this article to be further copied/distributed or hosted elsewhere without the express permission from SAGE Publications. 
NOT THE PUBLISHED VERSION; this is the author's final, peer-reviewed manuscript. The published version may be accessed by following the link in the citation at the bottom of the page.

Halpern, D. (2004). Obstacles to women full professorship: Another civilrights issue. APA Monitor on Psychology, 35(10), 5.

Hargens, L. L., \& Long, J. S. (2002). Demographic inertia and women's representation among faculty in higher education. Journal of Higher Education, 73, 494-517.

Heppner, P. P., Kivlighan, D. M., \& Wampold, B. E. (1999). Research design in counseling (2nd ed.). Belmont, CA: Brooks/Cole Wadsworth.

Hill, C. E., Knox, S., Thompson, B. J., Nutt-Williams, E., Hess, S., \& Ladany, N. (2005). Consensual qualitative research: An update. Journal of Counseling Psychology, 52, 196-205.

Hill, C. E., Nutt-Williams, E., Heaton, K. J., Thompson, B. J., \& Rhodes, R. H. (1996). Therapist retrospective recall of impasses in long-term psychotherapy: A qualitative analysis. Journal of Counseling Psychology, 43, 207-217.

Hill, C. E., Thompson, B. J., \& Nutt-Williams, E. (1997). A guide to conducting consensual qualitative research. The Counseling Psychologist, 25, 517572.

Hochschild, A. R. (1989). Second shift. New York, NY: Avon Books.

Kite, M. E., Russo, N. F., Brehm, S. S., Fouad, N. A., Iijima Hall, C. C., Hyde, J. S., et al. (2001). Women psychologists in academe: Mixed progress, unwarranted complacency. American Psychologist, 56, 1080-1098.

Knox, S., Burkard, A. W., Edwards, L. M., Smith, J. J., \& Schlosser, L. Z. (2008). Supervisors' reports of the effects of supervisor self-disclosure on supervisees. Psychotherapy Research, 18, 543-559.

Knox, S., Hess, S. A., Williams, E. N., \& Hill, C. E. (2003). "Here's a little something for you": How therapists respond to client gifts. Journal of Counseling Psychology, 50, 199-210.

Knox, S., Schlosser, L. Z., Pruitt, N. T., \& Hill, C. E. (2006). A qualitative examination of the advising relationship: Advisor perspective. The Counseling Psychologist, 34, 489-518.

Krefting, L. A. (2003). Intertwined discourses of merit and gender: Evidence from academic employment in the USA. Gender, Work, and Organization, 10, 260-278.

Lent, R. W., Brown, S. D., \& Hackett, G. (2002). Social cognitive career theory. In D. Brown (Ed.), Career choice and development (4th ed., pp. 255-311). San Francisco: Jossey-Bass.

London, M. (1998). Career barriers: How people experience, overcome, and avoid failure. Mahwah, NJ: Lawrence Erlbaum.

Matusov, E., \& Hampel, R. (2008, January-February). Two approaches to tenure and promotion criteria. Academe, 94(1), 37-39. Retrieved March, 2010, from http://www.aaup.org/AAUP/pubsres/academe/ National Science Foundation, Division of Science Resources Statistics. (2007). Science and engineering degrees: 1966-2004 (Special Report No. NSF

The Counseling Psychologists, Vol. 38, No. 8 (November 2010): pg. 1139-1173. DOI. This article is (C SAGE Publications and permission has been granted for this version to appear in e-Publications@Marquette. Sage Publications does not grant permission for this article to be further copied/distributed or hosted elsewhere without the express permission from SAGE Publications. 
07-307, Maurya Green, project officer). Arlington, VA. Retrieved October, 2009, from www.nsf.gov/statistics/nsf07307/

National Science Foundation, Division of Science Resources Statistics. (2008). Thirty-three years of women in S \& E faculty positions (Special Report No. NSF 08-308, Joan Burrelli, project officer). Arlington, VA. Retrieved October, 2009, from www.nsf.gov/statistics/infbrief/nsf08308/

Schlosser, L. Z., Knox, S., Moskovitz, A. R., \& Hill, C. E. (2003). A qualitative examination of graduate advising relationships: The advisee perspective. Journal of Counseling Psychology, 50, 178-188.

Sorcinelli, M. D. (1994). Effective approaches to new faculty development. Journal of Counseling and Development, 72, 474-479.

Super, D. E. (1990). A life-span, life-space approach to career development. In D. Brown \& L. Brooks (Eds.), Career choice and development: Applying contemporary theories to practice (2nd ed., pp. 197-261). San Francisco: Jossey-Bass.

Swanson, J. L., \& Fouad, N. A. (1999). Career theory and practice: Learning through case studies. Thousand Oaks, CA: Sage.

Van Giffen, K. (1990). Influence of professor gender and perceived use of humor on course evaluations. Humor, 3(1), 65-73. Downloaded from tcp.sagepub.com at MARQUETTE UNIV on February 25, 2011

\section{Appendix}

\section{Interview Protocol}

Thank you for your interest in this study of the pursuit of full professorship by academic women in counseling psychology. I am grateful for your time. The initial questions in this interview are designed to elicit a general overview of factors that may have affected your career, as well as your thinking specifically about pursuing full professorship. Please be assured that I will maintain strict confidentiality regarding this conversation. All identifying information will be deleted from the interview transcripts.

\section{General Questions}

1. Please describe your current professional position.

2. Please describe the professional goals you have for the remainder of your career.

3. What are the requirements for becoming a full professor at your university?

- Are these requirements written or implied?

The Counseling Psychologists, Vol. 38, No. 8 (November 2010): pg. 1139-1173. DOI. This article is @ SAGE Publications and permission has been granted for this version to appear in e-Publications@Marquette. Sage Publications does not grant permission for this article to be further copied/distributed or hosted elsewhere without the express permission from SAGE Publications. 
- How have these requirements been communicated to you?

- How well do you feel your qualifications compare to these criteria

4. What feedback, if any, have you received about your being promoted to full professor?

- Who gave you this feedback?

- Was it formal or informal feedback?

- Did you intentionally seek out this feedback?

5. What factors have influenced your thinking regarding whether or not to pursue full professorship?

6. What factors, if any, would change your thinking about pursuing full professorship?

7. In terms of your own career, what do you see as the positive outcomes of your decision to pursue full professorship?

- Which of these outcomes is most and least important to you?

8. In terms of your own career, what do you see as the negative outcomes of your decision to pursue full professorship?

- Which of these detriments is most and least important to you?

9. How, if at all, has the presence or absence of a mentor affected your thinking about full professorship?

\section{Critical Experiences}

Now I would like you to discuss some specific experience that may have affected your decision to pursue full professorship. For the first experience, I will ask you to describe a situation where your decision to pursue full professorship was encouraged in some way. The encouragement could be in the form of an interaction with another person (colleague, family member, etc.) or simply a situation or event (professional or otherwise) in your life. Please be assured that I will maintain strict confidentiality regarding this conversation. All identifying information will be deleted from the interview transcripts.

10.Please describe a specific experience where you received encouragement regarding your decision to pursue full professorship.

- What was the experience?

- When did this experience occur?

- What was your reaction to this experience?

The Counseling Psychologists, Vol. 38, No. 8 (November 2010): pg. 1139-1173. DOI. This article is @ SAGE Publications and permission has been granted for this version to appear in e-Publications@Marquette. Sage Publications does not grant permission for this article to be further copied/distributed or hosted elsewhere without the express permission from SAGE Publications. 
- What was the immediate effect (i.e., within one month) of this experience for you?

- What was the long-term effect (i.e., beyond one month) of this experience for you?

- Specifically, what aspect of this experience was encouraging to you?

- How did this experience affect your thinking about pursuing full professorship?

Thank you for relating that experience. I am now going to transition into the second critical experience. For the second experience, I will ask you to describe a situation where you faced an obstacle or challenge to your pursuit of full professorship. This challenge could be in the form of an interaction with another person (colleague, family member, etc.) or simply a situation or experience (professional or otherwise) in your life. Please be assured that I will maintain strict confidentiality regarding this conversation. All identifying information will be deleted from the interview transcripts.

11. Please describe a specific situation where you faced an obstacle or challenge regarding your decision to pursue full professorship.

- What was the experience?

- When did this experience occur?

- What was your reaction to this experience?

- What was the immediate effect (i.e., within one month) of this experience for you?

- What was the long-term effect (i.e., beyond one month) of this experience for you?

- Specifically, what aspect of this experience was challenging to you?

- How did this experience affect your thinking about pursuing full professorship?

\section{Closing Questions}

12. How, if at all, has your thinking about whether or not to pursue full professorship changed over your career as a faculty member?

13. Why did you agree to participate in this study?

14. How has this interview affected you? permission has been granted for this version to appear in e-Publications@Marquette. Sage Publications does not grant permission for this article to be further copied/distributed or hosted elsewhere without the express permission from SAGE Publications. 
NOT THE PUBLISHED VERSION; this is the author's final, peer-reviewed manuscript. The published version may be accessed by following the link in the citation at the bottom of the page.

15. Any final thoughts?

Set a date and time for the follow-up interview.

\section{Table 1}

\section{Participant Demographics}

\begin{tabular}{|c|c|c|c|}
\hline Item & Mean & Median & $\begin{array}{l}\text { Standard } \\
\text { Deviation }\end{array}$ \\
\hline Years before obtaining tenure-track job & 1.8 & 0.75 & 3.1 \\
\hline Years as assistant professor before tenure & 6.8 & 6.0 & 1.7 \\
\hline Years as associate professor & 5.8 & 5.5 & 2.5 \\
\hline Percentage of time devoted to research & 26.0 & 22.5 & 13.4 \\
\hline Percentage of time devoted to teaching & 22.7 & 20.0 & 8.6 \\
\hline Percentage of time devoted to administration & 15.0 & 7.5 & 18.0 \\
\hline Percentage of time devoted to advising & 14.5 & 14.0 & 5.9 \\
\hline Percentage of time devoted to service & 9.9 & 10.0 & 7.9 \\
\hline $\begin{array}{l}\text { Percentage of time devoted to professional } \\
\text { organizations }\end{array}$ & 6.6 & 5.0 & 5.1 \\
\hline $\begin{array}{l}\text { Percentage of time devoted to providing } \\
\text { psychotherapy }\end{array}$ & 6.2 & 3.5 & 7.9 \\
\hline Editorial boards served & 2.5 & 3.0 & 1.7 \\
\hline Local elected psychology officer & 1.3 & 0.0 & 2.9 \\
\hline National elected psychology officer & 0.3 & 0.0 & 0.6 \\
\hline National psychology awards & 1.1 & 0.0 & 2.1 \\
\hline Organizational fellowships & 0.8 & 0.0 & 0.3 \\
\hline Intramural grants & 3.2 & 3.0 & 2.7 \\
\hline Extramural grants & 1.3 & 1.0 & 1.8 \\
\hline Grant funding & $\$ 224,158$ & $\$ 52,000$ & $\$ 563,144$ \\
\hline Peer-reviewed articles & 16.2 & 16.0 & 8.2 \\
\hline Book chapters & 5.7 & 3.5 & 5.3 \\
\hline Books & 1.2 & 0 & 2.2 \\
\hline Total publications & 24.3 & 22.0 & 10.8 \\
\hline
\end{tabular}

The Counseling Psychologists, Vol. 38, No. 8 (November 2010): pg. 1139-1173. DOI. This article is @ SAGE Publications and permission has been granted for this version to appear in e-Publications@Marquette. Sage Publications does not grant permission for this article to be further copied/distributed or hosted elsewhere without the express permission from SAGE Publications. 
NOT THE PUBLISHED VERSION; this is the author's final, peer-reviewed manuscript. The published version may be accessed by following the link in the citation at the bottom of the page.

\section{Table 2}

\section{Contextual Findings}

\begin{tabular}{|c|c|c|c|}
\hline \multicolumn{2}{|c|}{ Domain } & Category & \\
\hline \multirow[t]{6}{*}{ I. } & Requilrements for: & Excellance in research & General \\
\hline & & $\begin{array}{l}\text { National reputation in research } \\
\text { arca }\end{array}$ & General \\
\hline & & $\begin{array}{l}\text { Continuaus record of } \\
\text { publication }\end{array}$ & Typical \\
\hline & & Effective teaching skilk & Varient \\
\hline & & Excallent service recond & Varkent \\
\hline & & Obtaining grants/external funding & Wariant \\
\hline \multirow[t]{4}{*}{2.} & $\begin{array}{l}\text { Communication of } \\
\text { requirements }\end{array}$ & & \\
\hline & Means & Written & General \\
\hline & & Implied (l.e. not written) & Typical \\
\hline & Ouality & Uncleanivague & Typical \\
\hline \multirow[t]{4}{*}{ 3. } & Feedback received & Department chair & Typical \\
\hline & & Dean & Variant \\
\hline & & Colleagues & Varkent \\
\hline & & None & Varkent \\
\hline \multirow[t]{6}{*}{4.} & Why pursuefull & Increased satary & Ganeral \\
\hline & & $\begin{array}{l}\text { Increased prestigedsatistaction of } \\
\text { reaching highest rank level }\end{array}$ & Eeneral \\
\hline & & $\begin{array}{l}\text { Increased powerinfluarce at } \\
\text { university }\end{array}$ & Variant \\
\hline & & $\begin{array}{l}\text { Strengzhen credientials for } \\
\text { adminiztrative positions }\end{array}$ & Varisent \\
\hline & & $\begin{array}{l}\text { Want to roach highest level of } \\
\text { profession }\end{array}$ & Varient \\
\hline & & Would help P be a role model & Varknt \\
\hline \multirow[t]{5}{*}{ 5. } & Why not pursue & Anxiefy abcat being rejected & Varkent \\
\hline & & $\begin{array}{l}\text { Less important than other } \\
\text { priorities }\end{array}$ & Variant \\
\hline & & Decreased professiona mobiliny & Varient \\
\hline & & $\begin{array}{l}\text { Previous negative tenure } \\
\text { experience }\end{array}$ & Varkant \\
\hline & & $\begin{array}{l}\text { No negative outcomas for } \\
\text { pursuing/being full professorship }\end{array}$ & Variant \\
\hline \multirow[t]{3}{*}{6.} & What weuid & Nothing & Typical \\
\hline & & $\begin{array}{l}\text { if told she would not get foll } \\
\text { professorship. }\end{array}$ & Variant \\
\hline & & $\begin{array}{l}\text { If university had an administration } \\
\text { charge }\end{array}$ & Variant \\
\hline \multirow[t]{3}{*}{7.} & Cument montoring & No current mentoring & Typical \\
\hline & & Lack of mentoring slowed caree: & Variant \\
\hline & & $\begin{array}{l}\text { Current mentoring has } \\
\text { encoursed participant to pursue } \\
\text { full prolessorship }\end{array}$ & Variatit \\
\hline
\end{tabular}

Note. Twelve total cases.

a General $=11-12 ;$ typical $=7-10 ;$ variant $=2-6$

The Counseling Psychologists, Vol. 38, No. 8 (November 2010): pg. 1139-1173. DOI. This article is @ SAGE Publications and permission has been granted for this version to appear in e-Publications@Marquette. Sage Publications does not grant permission for this article to be further copied/distributed or hosted elsewhere without the express permission from SAGE Publications. 
NOT THE PUBLISHED VERSION; this is the author's final, peer-reviewed manuscript. The published version may be accessed by following the link in the citation at the bottom of the page.

\section{Table 3}

\section{Critical Experiences}

\begin{tabular}{|c|c|c|c|}
\hline \multicolumn{2}{|c|}{ Domain } & Category & \multirow{2}{*}{$\frac{\text { Frequenc }}{\text { Typical }}$} \\
\hline I. & $\begin{array}{l}\text { Description of } \\
\text { encouraging critical }\end{array}$ & $\begin{array}{l}\text { Participant received supportive } \\
\text { feedback }\end{array}$ & \\
\hline & & $\begin{array}{l}\text { Participant published notable } \\
\text { research }\end{array}$ & Variant \\
\hline \multirow[t]{2}{*}{2.} & $\begin{array}{l}\text { Effect of encouraging } \\
\text { critical experience }\end{array}$ & $\begin{array}{l}\text { Encouraged participant to } \\
\text { pursue full professorship }\end{array}$ & General \\
\hline & & $\begin{array}{l}\text { Helped participant value self/ } \\
\text { work }\end{array}$ & Variant \\
\hline \multirow[t]{2}{*}{3.} & $\begin{array}{l}\text { Description of } \\
\text { discouraging critical }\end{array}$ & $\begin{array}{l}\text { Participant felt discriminated } \\
\text { against }\end{array}$ & Variant \\
\hline & & $\begin{array}{l}\text { Participant faced with decision } \\
\text { regarding life/career values }\end{array}$ & Variant \\
\hline \multirow[t]{4}{*}{4.} & $\begin{array}{l}\text { Effect of discouraging } \\
\text { critical experience }^{b}\end{array}$ & $\begin{array}{l}\text { Participant doubted her } \\
\text { qualifications }\end{array}$ & Typical \\
\hline & & $\begin{array}{l}\text { Discouraged pursuit of full } \\
\text { professorship }\end{array}$ & Variant \\
\hline & & $\begin{array}{l}\text { Participant felt rejected or } \\
\text { angered by colleagues' } \\
\text { behaviors }\end{array}$ & Variant \\
\hline & & $\begin{array}{l}\text { Over long term, participant } \\
\text { put event in perspective }\end{array}$ & Variant \\
\hline
\end{tabular}

The Counseling Psychologists, Vol. 38, No. 8 (November 2010): pg. 1139-1173. DOI. This article is @ SAGE Publications and permission has been granted for this version to appear in e-Publications@Marquette. Sage Publications does not grant permission for this article to be further copied/distributed or hosted elsewhere without the express permission from SAGE Publications. 